\title{
Evaluation of Factors Having Impact on Tax Compliance as Regards to Taxpayers: Application for the City of Kars
}

\author{
Alper TazegüL \\ Faculty of Economics and Administrative Sciences, Kafkas University, Kars, Turkey \\ Email: alper.tazegul2004@gmail.com
}

Received 27 June 2016; accepted 21 August 2016; published 24 August 2016

Copyright (C) 2016 by author and Scientific Research Publishing Inc.

This work is licensed under the Creative Commons Attribution International License (CC BY). http://creativecommons.org/licenses/by/4.0/

(c) (i) Open Access

\begin{abstract}
Tax means money taken from taxpayers by the state as obligatory and originating from the institution. Especially in countries like Turkey where an important part of income is generated from taxes, this resource is an irreplaceable finance tool. While the state uses this right arising from the constitution and the law, they must also act in accordance with the taxation principles as defined by the constitution and the law. There is also a special need to act in a sensitive way to ensure justice of taxation. Because taxpayers, who are the other parties related with taxation, won't participate in tax issues voluntarily if they come to believe that taxation is not being done in accordance with principles of justice and equity. As the tax compliance improves, the transactions related with taxation will be performed in a less problematic way. In this respect, the factors which have an impact on the tax compliance of taxpayers as voluntarily have been determined with this study by conducting area analysis. As a result of research made, it is seen that factors like gender, marital status, age, income level, and education cause different attitudes and behaviors as regards to tax approach.
\end{abstract}

\section{Keywords}

Tax, Tax Compliance, Factors Having Impact on Tax Compliance

\section{Introduction}

Taxes which are important finance sources for the state have become even more important with the changes that occured in the state approach in the last century. Because the change that occured in the state approach has increased the liabilities of the state considerably. In order to fulfill these liabilities, there is a need for constant and 
regular incomes. At this point, taxes appear as a finance tool almost with no alternative for the states.

Taxation is an important subject also for the taxpayers who make up the other party related with taxes. The fact that a portion of income generated is provided to the state without any returns, sometimes creates resistence at the taxpayers side. Therefore a situation occurs when one side tries to increase their income while the other side tries to reduce their financial burden. Especially when the ratio of tax incomes to the total incomes is considered in countries like Turkey, the subject becomes even more important. At this point, in order for the state to obtain tax incomes in a healthy and sustainable way, it is important for the taxpayers to have compliance as voluntarily.

There are many factors that can have an impact on the voluntary compliance of the taxpayers. Some of these factors could be listed as demographical factors, managerial-political factors, legal and social-economical factors, tax ethics, and accounting applications. With this study, the evaluation of some factors having impact on tax compliance as per taxpayers has been made as relating with the city of Kars with a questionnaire conducted.

\section{The Concept of Tax Compliance}

Tax compliance could be defined as realisation of tax liability among taxpayers in a rightful way [1]. This liability refers to making declaration of tax obligations as complete according to the tax law, legislations, and jurisdiction decisions at that time [2].

As tax compliance is a complex fact related with attitudes, it was examined by using different methods and data sources [3]. Because there are many variables influencing tax compliance, many factors like tax applications, social-economical structure, accounting applications, administrative structure, content of laws, and application methods in the country have positive or negative impact on tax compliance.

Besides some personal qualifications of taxpayers also influence tax compliance. These qualifications could be listed as age, educational level, personal behavioral ways of the taxpayers, social pressure on evasion, the though of taxpayers as regards to the tax load, and the tendency for evasion in the social or occupational group of which the liable person is a part of [4]. Economical dimensions/reasons of reaction of taxpayer as regards to taxation is an important phenomenon. But it is not possible to exppaing the reaction given to tax compliance only with economical factors. Ethical thoughts and norms which influence the personal benefits and attitudes of taxpayers also have an impact on tax compliance [5]. Cultural, religious, political, legal, managerial factors as part of the social life of taxpayers and other factors originating from the tax system itself also influence the tax compliance [6].

\section{Factors Having Impact on Tax Compliance}

\subsection{Demographical Factors}

Public positions/statutes of taxpayers like their gender, marital status, age, education level, and monthly income have an impact on their approach to tax issue. There can be a positive or negative impact between these factors and tax compliance of taxpayers.

It is inevitable for the education of taxpayers not to influence tax compliance. As the level of education will have an impact on whether arrangements made relating to taxation have been learned or not, they will influence tax compliance.

As the educational level increases and taxpayers get more conscious as regards to the function of taxation relating with public issues, the tendency for evasion reduces [7]. Income level of taxpayers also influences tax compliance. As researches made as regards to the impact of income level and tax ratios on voluntary compliance of taxpayers were analysed, it is seen that as income rises tax evasion also rises [8]. Marital status and age of taxpayers also influece voluntary compliance. But there is no consensus as regards to whether marital status has a positive or negative impact on voluntary compliance with taxation. According to some studies married people have higher tax compliance than single ones [3] whereas according to other studies, single people show higher tax compliance [9] [10].

\subsection{Legal Factors}

As the legal arrangements relating with taxation are more clear, understandable, and persuading and as relating with tax amnesties which are often made in Turkey, tax compliance of taxpayers is directly influenced. 
In this respect, "expanding tax controls" and "persuading with tax penalties" can be seen as important tools for providing tax compliance of taxpayers as voluntarily [11].

\subsection{Social-Economical Factors}

Taxpayers would like to see the reflection of taxes for which they have made payment directly on themselves. If taxpayers believe that this condition is not met, they will show resistance as per economical reasons. Similarly if taxpayers don't believe that tax load is justful, this would create a situation where taxpayers would evade tax in a reasonable way as per psychologic reasons [12].

\subsection{Political-Managerial Factors}

Just like in other areas to be successful in tax management, functionality of organisation and its effectiveness play an important role. Tax administation can realise the heavy work load expected from them only with a strategic organisation. This kind of a structure would also have a positive impact on the taxpayer and it will facilitate compliance.

Managerial issues like sources allocated for tax management, organisational structure of administration and taxpayers, keeping taxpayers as recorded, defining the types of taxation as per the structure of the country, and complexity of tax systemare important factors having impact on tax compliance [1]. Controls made by the tax administration also play an important role in tax compliance. Taxpayers' thinking that they may be audited one day will increase their tendency for acting in line with the laws [13].

\subsection{Factors Related with Tax Ethics}

Ethics is one of the basic institutional infrastructures required for social order. Ethical standing of both the tax administration and the individuals play an important role on tax compliance.

An important factor influencing voluntary compliance of individuals to tax issue is tax ethics [14]. Compliance shown as relating with tax ethics is a compliance that is independent of legal obligations relating with taxation.

\subsection{Factors Relating with Accounting Applications}

Accounting applications has an important role in voluntary compliance of taxpayers with tax issue. If the accounting applications are transparent, applicable, and understandable by the taxpayers, compliance with taxation will be facilitated. As accounting systems are insufficient in many developing countries, it becomes difficult to improve transparency [1]. This situation influences voluntary compliance of taxpayers to taxation in a negative way.

\section{Evaluation of Factors Having Impact on Tax Compliance as Regards to Taxpayers in the City of Kars}

\section{Methodology}

In order to determine the factors influencing tax compliance, face to face questionnaires were applied for defining the attitudes and behavior of taxpayers. This is an effective method in determining attitudes and behaviour [15].

A pilot trial application was conducted in provincial and district centers within the scale research sample according to the literature developed by the researcher in accordance with the research plan. Validity and reliability of the scale was calculated through analyzing the obtained data by virtue of the SPSS 16.0 software. Kuder-Richardson reliability test was applied and Cronbach's alpha reliability coefficient was calculated as 0.749 . Inasmuch as reliability coefficient of the entire scale's being $\alpha \geq 0.60$ shows the scale is sufficient and being $\alpha \geq$ 0.70 shows the scale has a high level of reliability [16], the scale was found to be reliable and applied to the entire sample.

Independent sample “t” test was conducted to determine if there were significant differences between the opinions of taxpayers who participated in the study as to the statements contained in each of the criteria according to the independent variables of "gender and marital status”. 
Furthermore, "one-way analysis of variance" (one-way ANOVA) "test was carried out to determine if there were significant differences between the opinions of taxpayers as to the statements contained in each of the criteria according to the independent variables of "age, education level and monthly income". To reveal the difference between opinions of the groups created according to each independent variable, "LSD" test was carried out in cases where the variables were homogeneous and "Tamhane's T2" test was carried out in cases where the variables were not homogeneous.

The sampling mass was determined as 376 people as per: $n=N t 2 p q / d 2(N-1)+t 2 p q \quad[=0.05$ meaning fulness level, and $\pm 5 \%$ ( $t=1.96, p=0.05, q=0.05$ ) sampling error].

In order for the results of questionnaire to reflect all of the city in general, the sampling mass was selected both from the center and from the provinces and applied accordingly. Questionnaire was applied to 421 taxpayers but 386 pieces of question forms were taken into evaluation.

Question form was composed of two sections. In the first section demographic information like the age, gender, marital status, educational level, and monthly income of taxpayers were analysed. In the second section of questionnaire, there were 20 questions. Questions of this section were composed of four parts which were legal factors, social-economical factors, political-managerial factors, and accounting applications. With these questions it was aimed to figure out the attitude and perception level of taxpayers. According to five dimensional likert collection scale, the answer choices were: “I absolutely agree, I agree, I am indifferent, I don’t agree, and I absolutely agree”. Analysis were conducted by using; "SPSS 16.0 for Windows statistical packaging program”.

\section{Analysis of Data}

\subsection{Demographic Qualities}

As the distribution of taxpayers participating in the research were analysed as per their gender, it is seen that 85 of them (22\%) were women and that 301 of them (78\%) were men. An important part of taxpayers being part of the sampling were junior high school graduates (40.4\%). $65.5 \%$ of them were married.

\subsection{Findings Relating with the Opinion of Taxpayers as Regards to the Evaluation of Factors Influencing Tax Compliance of Taxpayers}

In this section there are relational statistics in between variables like the gender, educational level, marital status, age, and monthly income of taxpayers and their opinions as regards to the factors influencing tax compliance.

While the findings were presented in Table 1 , in order to protect the integrity of subject matter and to avoid unnecessary details, each category was simplified in one table by providing "meaningfulness values". Again for the same reasoning, descriptive statistics of taxpayers' opinions were not presented.

Table 1. Demographic qualifications of the participants.

\begin{tabular}{cccccc}
\hline Age & $\mathrm{N}$ & $\%$ & Marital Status & $\mathrm{N}$ & $\%$ \\
\hline $18-24$ & 63 & 16.3 & Married & 253 & 65.5 \\
$25-30$ & 90 & 23.3 & Single & 133 & 34.5 \\
$31-35$ & 77 & 19.9 & Educational Status & $\mathrm{N}$ & $\%$ \\
$36-40$ & 65 & 16.8 & Elementary & 24 & 6.2 \\
41 and above & 91 & 23.6 & Junior High School & 57 & 14.8 \\
Income Status (TL) & $\mathrm{N}$ & $\%$ & High School & 156 & 40.4 \\
$0-1000$ & 63 & 16.3 & Associate Degree & 60 & 15.5 \\
$1001-2000$ & 117 & 30.3 & Undergraduate Degree & 80 & 20.7 \\
$2001-3000$ & 101 & 26.2 & Postgraduate Degree & 9 & 2.3 \\
$3001-4000$ & 57 & 14.8 & Gender & $\mathrm{N}$ & $\%$ \\
$4001+$ & 48 & 12.4 & Woman & 85 & 22.0 \\
& & & Man & 301 & 78.0 \\
\hline
\end{tabular}




\subsubsection{Findings Relating with Their Opinions as Regards to the Legal Factors Having Impact on the} Tax Compliance of Taxpayers

Descriptive statistics as based on data obtained from the answers given by taxpayers participating in the research relating with their opinions for "legal factors" effecting tax compliance were calculated and in order to determine whether there is a meaningful difference between the gender and marital status of taxpayers and their opinions. Independent group's t-test was applied. As relating with their educational status, age and monthly income single way variance analysis was applied. In order to define between which groups the differences emerged. LSD was applied when the variances were homogeneous and Tamhane's T2 tests were applied when they were not homogeneous and the analysis results were presented in Figure 1.

As regards to taxpayers' opinions relating with how effective and fast the tax jurisdiction process is carried out. There is a meaningful difference as per the gender variable statistically $[t=-0.877 ; p=0.016 ; p<0.05]$ $\left(\mathrm{X}_{\text {women }}=3.6000, \mathrm{X}_{\text {men }}=3.8272\right)$.

As regards to opinion of taxpayers relating with the requirement to have facilitating provisions for the tax laws. it is seen that there is a meaningful difference as per the variable of age factor statistically $[\mathrm{F}=3.116 ; \mathrm{p}=$ $0.015(\mathrm{p}<0.05)]$. As the variances are distributed as homogeneously for the item where difference was seen. LSD test was applied to specify between which groups the difference existed. The difference seen between the groups were observed for taxpayers with age group 36 - 40. age group 31 - 35. and age group above $41\left(X_{36-40}=\right.$ 4.1231, $\left.\mathrm{X}_{31-35}=4.5195, \mathrm{X}_{41+}=4.4945\right)$.

As regards to different decisions' being taken by tax courts. it was seen that there was a meaningful difference as regards to taxpayer opinions relating with the age variable statistically $[\mathrm{F}=3.140 ; \mathrm{p}=0.015(\mathrm{p}<0.05)]$. As

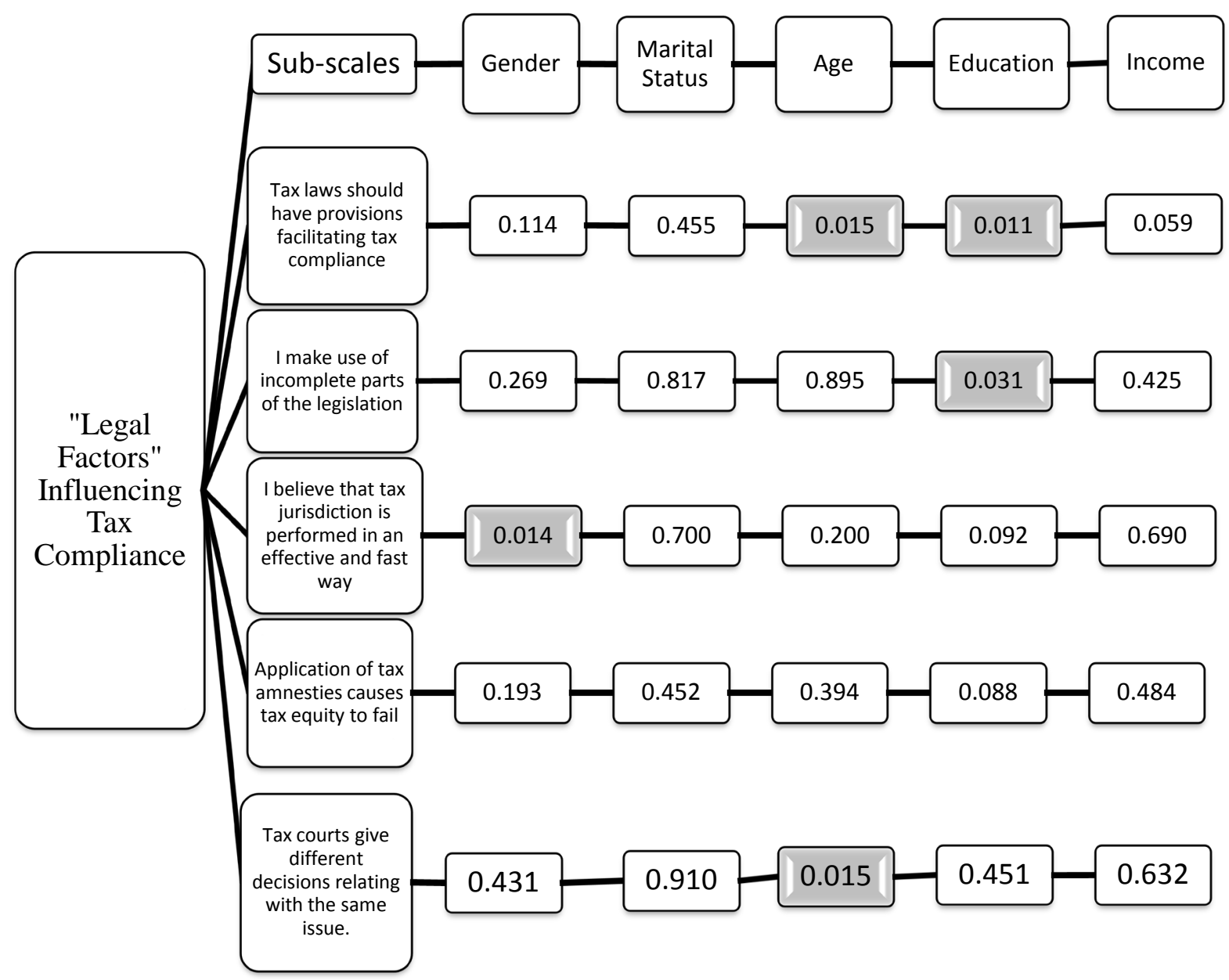

Figure 1. Results of independent T-test and ANOVA relating with the opinions of taxpayers as regards to legal factors influencing tax compliance of taxpayers. 
the variances were distributed as homogeneously. LSD test was applied to determine between which groups the difference existed. The difference between the groups were seen between taxpayers with ages higher than 41 and the taxpayers from the other age group $\left(\mathrm{X}_{41_{+}}=3.9011, \mathrm{X}_{36-40}=3.3692, \mathrm{X}_{31-35}=3.5584, \mathrm{X}_{25-30}=3.4444, \mathrm{X}_{18-24}=\right.$ 3.4762).

As relating to providing facilitating provisions to taxing law for tax compliance. a meaningful difference was found statistically between the opinions of taxpayers as per the variable of educational level $[\mathrm{F}=2.998$; $\mathrm{p}=$ $0.011(\mathrm{p}<0.05)]$. As the variances relating with the item where difference was found were distributed homogeneously. LSD test was applied to find out between which groups a difference existed.

The difference between groups was observed for the taxpayers who had undergraduation degree and those taxpayers who were elementary school, junior high school or high school graduates $\left(\mathrm{X}_{\text {bachelor degree }}=4.4625\right.$, $\left.\mathrm{X}_{\text {elementary school }}=3.9167, \mathrm{X}_{\text {junior high school }}=3.9649, \mathrm{X}_{\text {high school }}=4.1154\right)$.

Relating with benefiting from legal spaces left in the legislation. a meaningful difference was observed between opinions of taxpayers as per the variable of educational level statistically $[F=2.998 ; p=0.031(p<0.05)]$. As the variances were distributed homogeneously for the item where difference was found. LSD test was applied for finding out between which groups the difference existed.

The difference between groups was observed among taxpayers who were elementary school graduates and those who were junior high school graduates or who had postgraduation degrees $\left(\mathrm{X}_{\text {elementary school }}=3.0000, \mathrm{X}_{\text {junior }}\right.$ high school $=2.3684, \mathrm{X}_{\text {post graduate }}=1.8889$ ).

\subsubsection{Findings Relating to Opinion of Taxpayers as Regards to Social-Economical Factors Influencing Tax Compliance of Taxpayers}

Tests were applied on the data obtained from the answers of taxpayers participating in the research as regards to their opinions relating with "Social-Economical” factors influencing tax compliance and the results are presented in Figure 2.

As regards to the statement that one of the important factors influencing tax compliance is tax bureaucracy. A meaningful difference was seen between the opinions of taxpayers as per the variable of gender statistically $[\mathrm{t}=$ $-0.877 ; \mathrm{p}=0.016 ; \mathrm{p}<0.05]\left(\mathrm{X}_{\text {women }}=3.8235, \mathrm{X}_{\text {men }}=3.7076\right)$.

Relating with the proposition that the attempts of taxpayers to reduce their tax loads is ethical. a meaningful difference was found between the opinions of taxpayers as per the variable of marital status statistically [ $\mathrm{t}=$ $-0.319 ; \mathrm{p}=0.018 ; \mathrm{p}<0.05]\left(\mathrm{X}_{\text {married }}=3.5415, \mathrm{X}_{\text {single }}=3.5865\right)$.

As regards to the sufficiency of impact of ethical rules on avoiding tax losses and evasions. a meaningful difference was found between the opinions of taxpayers as per the variable of age level statistically $[\mathrm{F}=2.969 ; \mathrm{p}=$ $0.020(p<0.05)]$. As the variences distributed homogeneously for the item where the difference was seen. LSD test was applied to find out between which groups the difference existed. It was observed that the difference among the groups existed for the taxpayers with ages above 41. and those taxpayers with age intervals of 18 - 24 . $25-30$ and $31-35\left(\mathrm{X}_{41+}=4.3297, \mathrm{X}_{18-24}=3.8889, \mathrm{X}_{25-30}=3.8889, \mathrm{X}_{31-35}=3.7662\right)$.

As relating with the requirement to improve the educational level of people in order to improve tax awareness. a meaningful difference was seen between the opinion of taxpayers as per the variable of educational level statistically $[F=2.498 ; p=0.030(p<0.05)]$. As the variances distributed homogeneously for the item where the difference was observed. LSD test was applied to find out between which groups the difference existed. The difference between the groups was seen among the taxpayers who had bachelor's degree and those who were elementary school, junior high school, or high school graduates $\left(\mathrm{X}_{\text {undergraduate }}=4.4625, \mathrm{X}_{\text {elementary school }}=3.9167\right.$, $\left.\mathrm{X}_{\text {junior high school }}=3.9649, \mathrm{X}_{\text {high school }}=4.1154\right)$.

As relating to the sufficiency of ethical rules for avoiding tax losses and evasion. a meaningful difference was seen among the opinions of taxpayers as per the variable of educational level statistically $[F=3.615 ; p=0.003$ $(p<0.05)]$. As the variances for the item where the difference was observed distributed homogeneously. in order to find out between which groups the difference existed. LSD test was applied. The difference between the groups was observed among taxpayers who were elementary school graduates and those who were graduated from other schools $\left(X_{\text {elementary school }}=3.2083, X_{\text {junior high school }}=4.2982, X_{\text {high school }}=3.9038, X_{\text {associate degree }}=4.0333\right.$, $\left.\mathrm{X}_{\text {bachelor's degree }}=4.0875, \mathrm{X}_{\text {postgraduate }}=4.4444\right)$.

Relating to the statement that one of the important factors effecting tax compliance is bureaucracy, a meaningful difference was seen among the opinions of taxpayers as per the variable of educational level statistically $[F=2.253 ; p=0.049(p<0.05)]$. As the variances distributed homogeneously for the item where the 


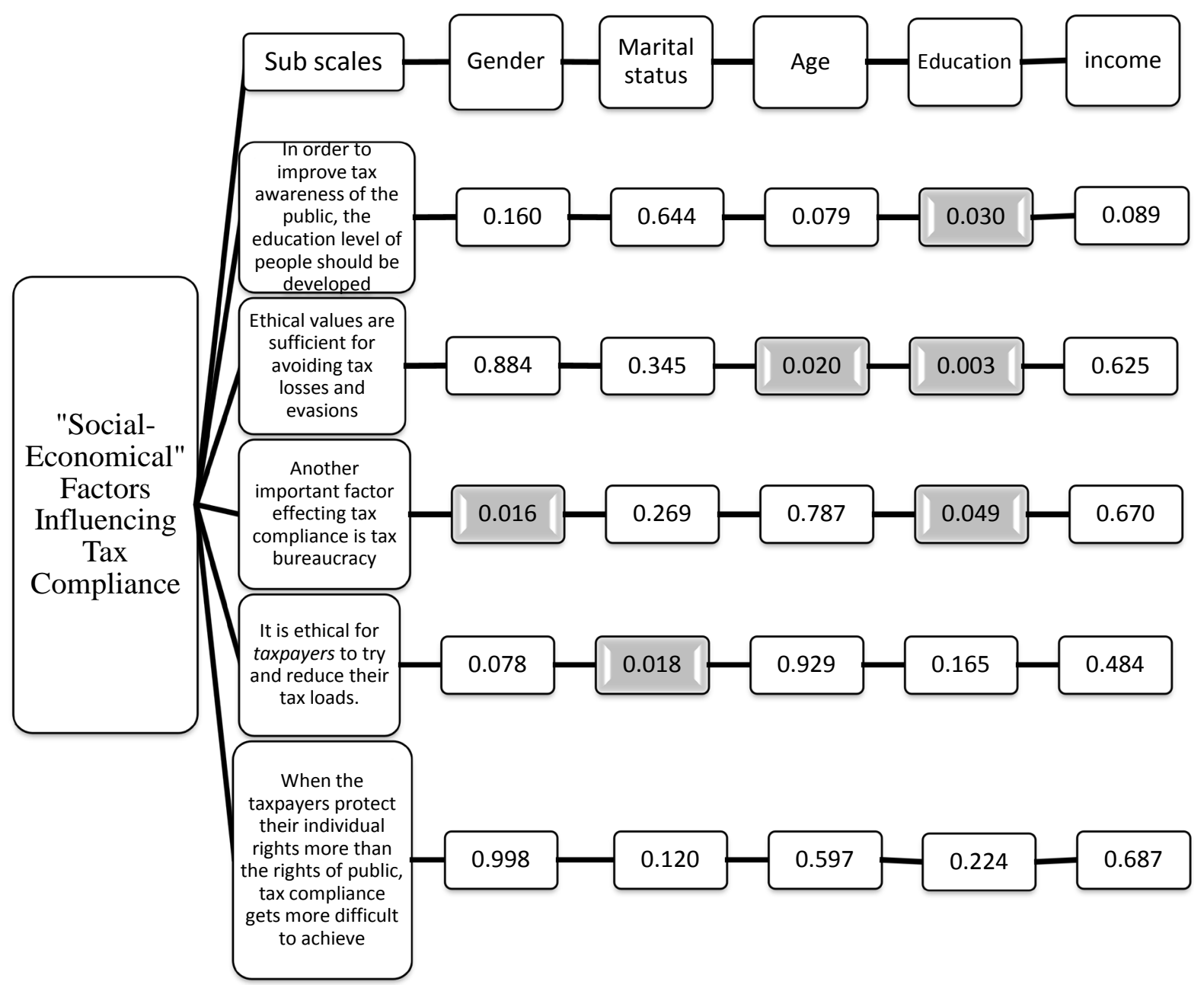

Figure 2. Independent T-test and ANOVA results relating with the opinion of taxpayers as regards to the impact of socialeconomical factors on tax compliance.

difference was seen. LSD test was aookşed to find out among which groups the difference existed. The difference among the groups was seen between taxpayers who were high school graduates and those who had bachelor's degree $\left(\mathrm{X}_{\text {high school }}=3.5833, \mathrm{X}_{\text {bachelor's degree }}=4.0375\right)$.

\subsubsection{Findings Relating to the Opinions of Taxpayers as Regards to the Accounting Applications Having Impact on Tax Compliance of Taxpayers}

Tests were applied on the data obtained from the answers given by taxpayers participating in research as regards to "accounting applications" that effect tax compliance, and the results of analysis are presented in Figure 3.

As regards to the statement that necessary measures are taken for avoiding accounting fraud aiming to show the situation of enterprise in a much better way. A meaningful difference was seen between the opinion of taxpayers as per the variables of gender and marital status statistically $[\mathrm{t}=1.469 ; \mathrm{p}=0.035 ; \mathrm{p}<0.05]\left(\mathrm{X}_{\text {women }}=\right.$ 3.6118, $\left.X_{\text {men }}=3.3522\right)[t=1.906 ; p=0.032 ; p<0.05]\left(X_{\text {married }}=3.3083, X_{\text {single }}=3.6015\right)$.

As relating to taking the necessary measures for avoiding accounting fraud aiming to show the situation of enterprise in a much better way. a meaningful difference was found among the opinion of taxpayers as per the variable of age level statistically $[F=2.826 ; p=0.025(p<0.05)]$. As the variances for the item where the difference was found distributed homogeneously. LSD test was applied to determine between which groups the difference existed. It was seen that the difference between the groups existed among taxpayers with age interval $18-24$ and taxpayers with age interval $31-35$ and those with age interval $36-40\left(\mathrm{X}_{18-24}=3.6508, \mathrm{X}_{31-35}=\right.$ 3.0909, $\left.\mathrm{X}_{36-40}=3.1077\right)$. 


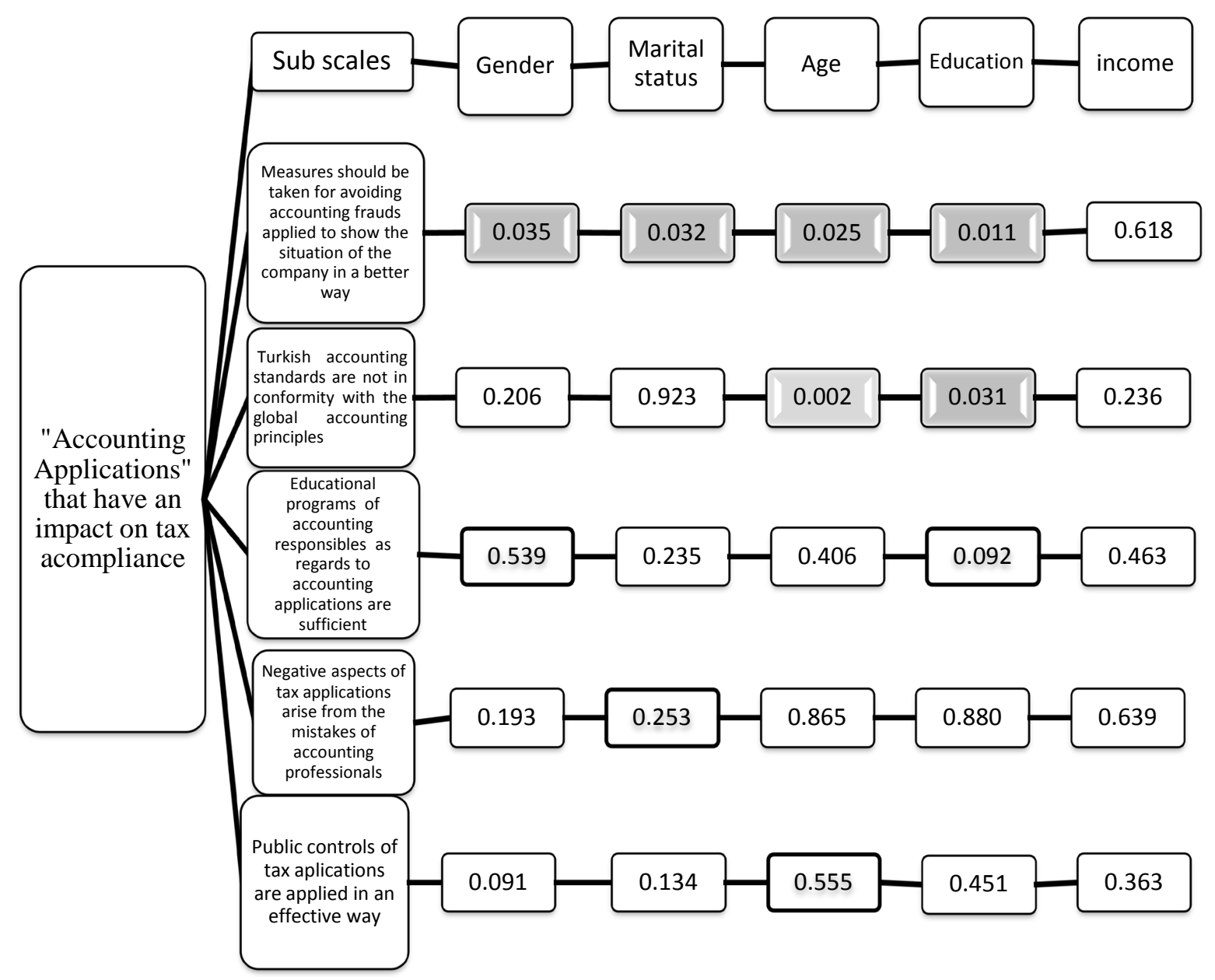

Figure 3. Independent T-test and ANOVA results as regards to opinion of taxpayers relating to the accounting applications that have an impact on tax compliance.

As relating to Turkish accounting standards' being in conformity with international accounting standards. a meaningful difference was seen among the opinion of taxpayers as per the variable of age level statistically $[\mathrm{F}=$ 4.434; $\mathrm{p}=0.031(\mathrm{p}<0.05)$ ]. As the variances for the item where the difference was seen distributed homogeneously. LSD test was applied to find out between which groups the difference existed. It was seen that the difference among the groups existed between taxpayers with age groups other than those with ages above 41 and those with age interval $36-40\left(\mathrm{X}_{41+}=3.9011, \mathrm{X}_{18-24}=3.4762, \mathrm{X}_{25-30}=3.3444, \mathrm{X}_{31-35}=3.4286\right)$.

\subsubsection{Findings Relating to the Opinion of Taxpayers as Regards to Political and Managerial Factors Having Impact on Tax Compliance of Taxpayers}

Tests were applied on data obtained from the answers given by taxpayers as regards to "Political and Managerial Factors" influencing tax compliance and the results of analysis are provided in Figure 4.

As regards to distribution of tax load to public in an appropriate and acceptable way, the statement that disturbances relating to political structures and public expenses spent for reasons not clearly known have negative impact on tax issue, being able to benefit from public services sufficiently despite the taxes that are paid, the statement that complex processing and problems experienced during taxation process increases noncompliance with tax issue, and as regards to improving planning and coordination in tax controls. a meaningful difference could not be seen among the opinion of taxpayers as per the variable of gender and educational level statistically.

As relating to benefiting from public services despite the taxes paid, a meaningful difference was seen among the opinion of taxpayers as per the variable of marital status statistically $[\mathrm{t}=-1.675 ; \mathrm{p}=0.040 ; \mathrm{p}<0.05]$ 


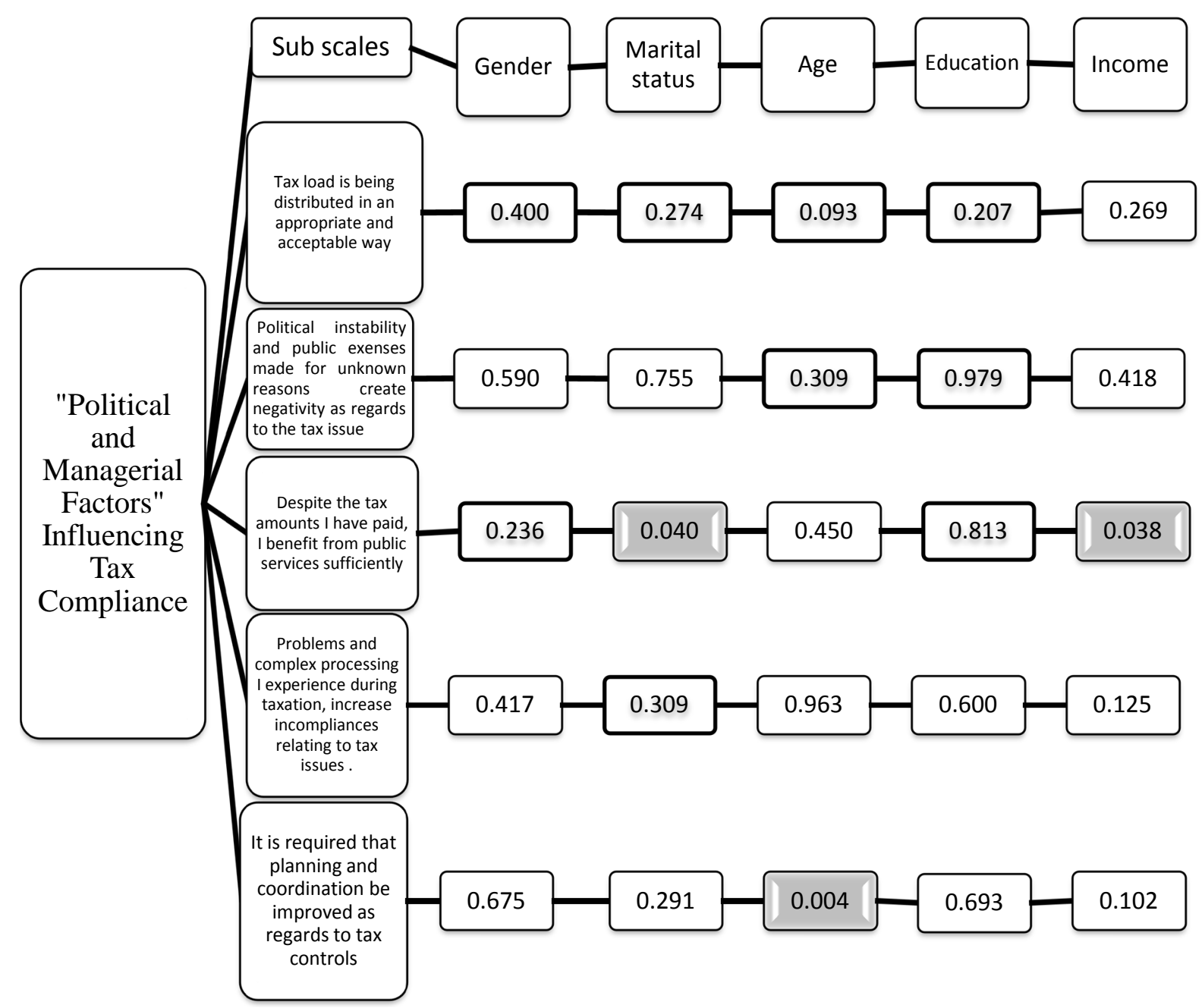

Figure 4. Results of independent T-test and ANOVA relating with the opinion of taxpayers as regards to political and managerial factors having impact on tax compliance.

$\left(\mathrm{X}_{\text {married }}=4.1344, \mathrm{X}_{\text {single }}=4.0075\right)$.

As relating to improving the effectiveness of planning and coordination in tax controls. A meaningful difference was seen among the opinion of taxpayers as per the variable of age level statistically $[F=3.874 ; p=0.004$ $(p<0.05)]$. As the variances for the item where the difference was found distributed homogeneously. LSD test was applied for finding out among which groups the difference was seen. The difference observed among the groups was seen between taxpayers with ages other than those higher than 41 and those with age interval 31 - 35 $\left(\mathrm{X}_{41+}=4.4725, \mathrm{X}_{18-24}=3.9683, \mathrm{X}_{25-30}=4.0444, \mathrm{X}_{36-40}=4.2000\right)$.

As relating to benefiting from public services sufficiently despite the taxes paid. A meaningful difference was observed among the opinion of taxpayers as per the variable of income level statistically $[F=2.562 ; p=0.038 ; p$ $<0.05]$. As the variances for the item where the difference was seen distributed homogeneously. LSD test was applied for determining among which groups the difference was observed. The difference among the groups was seen for those with income level between 2001 - $3000 \mathrm{TL}$ and those with income levels between 0 - 1000 TL and $1001-2000 \mathrm{TL}\left(\mathrm{X}_{2001-3000+}=3.6139, \mathrm{X}_{0-1000}=4.0952, \mathrm{X}_{1001-2000}=4.0085\right)$.

\section{Conclusions}

Incomes generated from taxes are used for financing the investments and services to be provided to the whole public. Especially when the ratio of tax incomes as part of public incomes is considerably high in countries like 
Turkey, it is very important for the tax amounts to be collected. Even though the collected taxes are used for the wellfare and development of public, taxpayers can still try to make tax evasions. In order to make collection of taxes successfully, a well organised administration may not always be enough. At this point, it is very important for taxpayers to adjust with tax issue as voluntarily.

There are many factors influencing voluntary compliance to the tax issue. Factors like the content and understandability of legal arrangements, reflections of accounting applications, social-economical structure, and political-managerial structure influence voluntary compliance with taxation. Besides, factors like the age, marital status, gender, educational level of taxpayers also influence voluntary compliance with tax issue. In this respect, some of the factors that can influence voluntary compliance with taxation have been analysed as per the opinion of taxpayers.

As regards to effectiveness and speed of tax jurisdiction, structure of tax bureaucracy, and taking measures for avoiding accounting fraud, it is seen that taxpayers had different opinions as per the variable of gender. Taxpayers who are women have more positive opinion about tax jurisdiction process and tax bureaucracy when compared with taxpayers who are men. As regards to providing provisions to tax laws for facilitating tax compliance, a meaningful difference was observed as per the variables of both age and educational level. It was especially seen that taxpayers who were 41 years old or above supported this statement even more. Meaningful differences were found as regards to benefiting from legal spaces in legislation. It is seen that taxpayers who were elementary school graduates agreed with this statement with a higher ratio.

As regards to statements as "It is possible to improve tax awareness of community by increasing the educational levels". "Ethical rules are sufficient for avoiding tax losses and evasion" and "One of the important factors in tax compliance is tax bureacuracy". It was seen that taxpayers had different opinions as per their educational status. It was especially observed that taxpayers who were elementary school graduates had more negative opinion as regards to the statement that ethical rules are enough for avoiding tax losses and evasion.

As regards to taking measures against accounting fraud made for showing the status of enterprises in a better way, it was seen that taxpayers had different opinions as per their gender, marital status, age, and educational status. Relating with this, it was seen that taxpayers who were men and those who were married had more negative opinion.

As regards to benefiting from public services sufficiently despite the taxes that were paid, it was observed that taxpayers had different opinion as per their marital status and income levels. It was seen that single taxpayers had more negative opinion relating with this issue.

Just like in other researches conducted, it is seen with this study that there are many factors that have an impact on voluntary compliance of taxpayers with the tax issue. Therefore, when legal or managerial arrangements are made relating to tax issues and as they are applied, if the sensitivity of taxpayers is taken into consideration, then more successful results can be achieved.

\section{References}

[1] Tunçer, M. (2002) Effect of Government-Individual Relations on Tax Compliance and Turkey. Faculty of Political Sciences, Ankara University, 57-53

[2] Roth, J.A., Scholz, J.T. and ve Witte, A.D. (1989) Taxpayer Compliance. Vol. 1, University of Pennsylvania, Philadelphia.

[3] Torgler, B. and ve Schneider, F. (2004) Does Culture Influence Tax Morale? Evidence from Different European Countries. CREMA Working Paper No. 17. http://www.crema-research.ch/papers/2004-17.pdf

[4] Batirel, Ö.F. (1996) Tax Evasion and Tax Voluntary Compliance. Tax World Journal, 16, No. 175.

[5] Wenzel, M. (2005) Motivation or Rationalisation? Causal Relations Between Ethics. Norms and Tax Compliance. Journal of Economic Psychology, 26, 491-508. http://dx.doi.org/10.1016/j.joep.2004.03.003

[6] Aktan, C.C., Dileyici, D. and Vural, İ.Y. (2006) Taxation Economics and Taxation Psychology. Ankara Seçkin Publishing, Ankara.

[7] Fallan, L. (1999) Gender, Exposure to Tax Knowledge and Attitudes Toward Taxation: An Experimental Approach. Journal of Business Ethics, 18, 173-184. http://link.springer.com/article/10.1023\%2FA\%3A1005711905297\#page-1

[8] Tuay, E. and Güvenç, İ. (2007) Opinion of Tax Payers in on Tax. Turkey Revenue Administration-Taxpayer Services Department, Issue No. 51. 
http://www.gib.gov.tr/fileadmin/beyannamerehberi/turkiyede_mukelleflerin_vergiye_bakisi.pdf

[9] İpek, S. and Kaynar, İ. (2009) An Empirical Study on Voluntary Tax Compliance in Çanakkale Province Celal Bayar University. Vol. 16. No. 1, Faculty of Economics and Administrative Sciences, Management and Economics, Manisa.

[10] İpek, S. and Kaynar, İ. (2009) Effect of Demographic Factors on Tax Compliance: Results of a Survey. Journal of Finance, 157.

[11] Tayfun, Ș. (2012) Recommendations for Taxpayer Tax Voluntary Compliance and Application Thereof. http://www.vmhk.org.tr/mukelleflerin-vergiye-gonullu-uyumu-ve-uygulama-icin-oneri/

[12] Uçak, C. (1997) Psychology of Taxation. Tax World Magazine, No. 89, 13-37.

[13] Çelikkaya, A. (2002) Factors Affecting the Voluntary Compliance of Tax Payers. e-Academy, Law, Economics and Political Science Monthly Internet Magazine, Issue 5. http://www.e-akademi.org/makaleler/acelikkaya-1.htm

[14] Aktan, C.C. (2006) Basics of Tax Psychology and Tax Ethics. Taxation Economics and Taxation Psychology (ss. 125-136). Seçkin Publishing, Ankara.

[15] Baş, T. (2001) Survey. Seçkin Publishing, Ankara.

[16] Özdamar, K. (2011) Statistical Data Analysis by Virtue of Package Software Programs. 8th Edition, Kaan Bookstore, Eskisehir.

\section{Submit or recommend next manuscript to SCIRP and we will provide best service for you:}

Accepting pre-submission inquiries through Email. Facebook. LinkedIn. Twitter. etc. A wide selection of journals (inclusive of 9 subjects. more than 200 journals)

Providing 24-hour high-quality service

User-friendly online submission system

Fair and swift peer-review system

Efficient typesetting and proofreading procedure

Display of the result of downloads and visits. as well as the number of cited articles

Maximum dissemination of your research work

Submit your manuscript at: http://papersubmission.scirp.org/ 